\title{
Integrasi Nilai Karakter Melalui Permainan Tradisional Tarik Tambang Dalam Pembelajaran IPA
}

\author{
${ }^{*}$ Ferina Agustini ${ }^{1}$ \\ ${ }^{1}$ Prodi pendididikan guru sekolah dasar, Universitas Negeri Semarang, Semarang, Indonesia
}

\section{A R T I C L E I N F O}

Article history:

1 Maret 2020 Received in

revised form

30 Maret 2020

Accepted 11 April 2020

Available online 15

Mei 2020

Kata Kunci:

Nilai Karakter,

Permainan Tradisional

Tarik Tambang,

Pembelajaran IPA SD

Keywords:

Character Value,

Traditional game Tug of

War, Natural Science

Learning in Elementary

srhonl

\begin{abstract}
A B S T R A K
Penelitian ini bertujuan untuk mengetahui integrasi nilai karakter melalui permainan tradisional tarik tambang dalam pembelajaran IPA di SDN Pleburan 03 Semarang. Hal ini berdasarkan pada semakin dilupakan dan ditinggalkannya permainan tradisional sebagai warisan leluhur. Permainan tradisional sangat besar pengaruhnya terhadap perkembangan jiwa, fisik, dan mental anak. Permainan tradisional juga dapat untuk mengembangkan nilai karakter anak. Penelitian ini merupakan penelitian deskriptif kualitatif yang diarahkan untuk mengetahui integrasi nilai karakter melalui permainan tradisional tarik tambang dalam pembelajaran IPA di SDN Pleburan 03 Semarang. Subjek dalam penelitian ini adalah SDN Pleburan 03 Semarang. Data diperoleh melalui angket dan wawancara kemudian peneliti melakukan analisis terhadap hasil angket dan hasil wawancara. Data yang telah terkumpul lalu diuji keabsahannya melalui triangulasi sumber dan teknik. Hasil temuan didapatkan bahwa nilai karakter yang muncul melalui permainan tradisional tarik tambang dalam pembelajaran IPA adalah kerjasama. Melalui permainan tersebut siswa mendapatkan
\end{abstract} pengalaman belajar yang bermakna berkaitan dengan materi gerak dan gaya.

\section{A B S T R A C T}

The aimed of this research was to determine the integration of character values through the traditional game tug of war in learning natural science in SDN Pleburan 03 Semarang. This was based on the forgotten and abandoned of traditional game as the heritage of ancestor. Traditional games had a profound effect on the mental, physical and mental development of children. Traditional games could also develop children's character values. This research was a qualitative descriptive which was aimed in finding out the integration of character values through traditional game tug of war in learning natural science in SDN Pleburan 03 Semarang. The subject in this research was the students in SDN Pleburan 03 Semarang. Data was obtained through questionnaires and interviews then researcher conducted an analysis of the results of the questionnaire and the results of the interview. The data that had been collected then tested for validity through triangulation of sources and techniques. The findings showed that the character value through the traditional game tug of war in learning natural science was cooperation. Through this game, students got a meaningful learning experience related to motion and force material.

\section{Pendahuluan}

Permainan tradisional anak-anak saat ini jarang dimainkan, bahkan sudah mulai ditinggalkan. Anak-anak zaman sekarang cenderung lebih memilih permainan modern, seperti playstation dan game online. Padahal dalam permainan tradisional tersimpan makna persatuan dan kebersamaan. Beberapa permainan tradisional yang kini sudah mulai ditinggalkan anak-anak antara lain yaitu gobak sodor, tarik tambang, engklek dan masih banyak lagi yang lainnya. Permainan itu kini sudah sangat jarang dimainkan. Perkembangan teknologi yang pesat, juga merupakan salah satu faktor yang menyebabkan permainan sederhana tersebut tak lagi menjadi permainan favorit anak zaman sekarang (kompas.com 01 Juni 2011). Hal ini seperti yang diungkapkan pada hasil survey pemakaian internet remaja Indonesia berdasarkan

Copyright (C) Universitas Pendidikan Ganesha. All rights reserved 
media Online kompas.com 19 Februari 2014 menyatakan bahwa hasil penelitian terbaru mencatat pengguna internet di Indonesia yang berasal dari kalangan anak-anak dan remaja diprediksi mencapai 30 juta. Penelitian tersebut juga mencatat ada kesenjangan digital yang kuat antara anak dan remaja yang tinggal di perkotaan dengan yang tinggal di pedesaan. Data tersebut merupakan hasil penelitian berjudul "Keamanan Penggunaan Media Digital pada Anak dan Remaja di Indonesia" yang yang dilakukan lembaga PBB untuk anak-anak, UNICEF, bersama para mitra, termasuk Kementerian Komunikasi dan Informatika dan Universitas Harvard, AS. Studi ini menelusuri aktivitas online dari sampel anak dan remaja yang melibatkan 400 responden berusia 10 sampai 19 tahun di seluruh Indonesia dan mewakili wilayah perkotaan dan pedesaan. Sebanyak 98 persen dari anak dan remaja mengaku tahu tentang internet dan 79,5 persen di antaranya adalah pengguna internet. Selain itu dalam berita media Online tribunnews.com pada hari Sabtu 7 Oktober 2017 menyatakan bahwa Remaja 21 tahun menderita kebutaan setelah 24 jam bermain game tanpa henti via smartphone. Hal ini berdampak pada semakin dilupakan dan ditinggalkannya permainan tradisional sebagai warisan leluhur. Padahal, permainan tradisional sangat besar pengaruhnya terhadap perkembangan jiwa, fisik, dan mental anak (Sisca, 2012).

Permainan tradisional ini tumbuh dan berkembang berdasarkan kebutuhan masyarakat di suatu tempat (Yunus, 1981). Menurut Subagiyo (dalam Mulyani, 2016) permainan tradisional adalah permainan yang tumbuh dan berkembang di suatu daerah. Permainan tradisional dimainkan oleh anak-anak dalam lingkungan masyarakat umum untuk menyerap kearifan lokal di daerah tersebut. Permainan tradisional dapat dimanfaatkan sebagai media pembelajaran bagi anak sehingga bisa mendukung tumbuh kembang anak dari berbagai aspek. Tientje, dkk., (2004) menyebutkan bahwa permainan tradisional yang berkembang di Indonesia mirip dengan olah raga. Permainan tradisional memiliki aturan main, bertujuan untuk memberi kesenangan, relaksasi, kegembiraan, serta tantangan. Menurut penelitian (Kurniati, 2011), interaksi yang terjadi pada saat anak melakukan permainan tradisonal memberikan kesempatan untuk mengembangkan kemampuan sosial, bahasa, dan emosi. Bahkan permainan tradisional dapat menstimulasi perkembangan anak dalam hal kerja sama, penyesuaian diri, interaksi sosial, kontrol diri, serta sikap empati dan saling menghargai. Kurniati (2011) juga menambahkan bahwa permainan tradisional dapat memberikan dampak positif pada pengembangan potensi anak. Permainan tradisional lebih mengutamakan kerja sama dibandingkan permainan modern, sehingga anak dapat bersosialisasi dan bekerja sama.

Permainan tradisional juga dapat untuk mengembangkan nilai karakter anak. Berdasarkan hasil penelitian Kurniati dalam (Nur, 2013) menunjukkan bahwa permainan anak tradisional dapat menstimulasi anak dalam mengembangkan kerjasama, membantu anak menyesuaikan diri, saling berinteraksi secara positif, dapat mengkondisikan anak dalam mengontrol diri, mengembangkan sikap empati terhadap teman, menaati aturan, serta menghargai orang lain. Dengan demikian, dapat dipahami bahwa permainan tradisional dapat memberikan dampak yang sangat baik dalam membantu mengembangkan keterampilan emosi dan sosial anak. Pengembangan nilai karakter merupakan usaha yang dapat dilakukan untuk mencegah keinginan melakukan perbuatan yang tidak baik. Nilai karakter harus ditanamkan siswa sejak dini, sehingga dapat membantu dirinya untuk bisa menahan keinginan melakukan perbuatan yang tidak baik dan lebih mengutamakan perbuatan yang baik kepada sesame. Oleh karena itu, karakter merupakan ciri dari diri seseorang yang sudah ada sejak lahir yang akan membedakan ciri dirinya dengan orang lain.

Menurut Haryati (Kusmilawati, Hadi, \& Agustini, 2019) penataan pendidikan nasional Indonesia dimulai dengan menempatkan kembali karakter sebagai dimensi dalam pendidikan nasional yang berdampingan dengan intelektualitas yang tercermin dalam kompetensi. Pada masa pemerintahan Presiden Joko Widodo saat ini telah dirumuskan program nawacita, salah satu programnya adalah memperkuat pendidikan karakter bangsa sebagai bagian dari Gerakan Nasional Revolusi Mental (GNRM) dalam bidang pendidikan. Pada jenjang siswa Sekolah Dasar, metode yang dapat dilakukan guru di sekolah adalah dengan pengarahan, peneladanan, pembiasaan, penguatan, penghargaan dan hukuman. Nilai-nilai karakter yang dapat dikembangkan Guru dalam pembelajaran sesuai dengan Kementerian Pendidikan dan Kebudayaan (Hamid, 2013) mengidentifikasi ada 18 nilai yang bersumber dari Agama, Pancasila, budaya, yang sesuai dengan tujuan pendidikan nasional yaitu: (1) religius, (2) jujur, (3) toleransi, (4) disiplin, (5) kerja keras, (6) kreatif, (7) mandiri, (8) demokratis, (9) rasa ingin tahu, (10) semangat kebangsaan, (11) cinta tanah air, (12) menghargai prestasi, (13) bersahabat/komunikatif, (14) cinta damai, (15) gemar membaca, (16) peduli lingkungan, (17) peduli sosial, dan (18) tanggung jawab.

Ki Hajar Dewantara menganjurkan adanya syarat-syarat yang diperlukan dalam permainan, khususnya permainan anak yang bertujuan untuk pendidikan (Purwaningsih, 2006). Adapun syarat- 
syarat untuk permainan anak adalah: Permainan harus menggembirakan anak karena kegembiraan adalah pupuk bagi tumbuhnya jiwa; Permainan harus memberi kesempatan pada anak untuk berfantasi. Permainan harus mengandung semacam tantangan sehingga merangsang daya kreativitas anak; Permainan hendaknya mengandung unsur keindahan atau nilai seni; dan Permainan anak harus mengandung isi yang dapat mendidik anak ke arah ketertiban, kedisplinan, sportifitas, kebersamaan.

Keunggulan dari permainan tradisional dapat dimanfaatkan menjadi sebuah metode dalam pembelajaran terutama di sekolah dasar. Selain itu permainan tradisional juga dapat diintegrasikan dalam beberapa mata pelajaran di sekolah dasar, salah satunya pembelajaran Ilmu Pengetahuan Alam (IPA). IPA memiliki karakteristik yang tidak sama dengan mata pelajaran yang lain. Pada proses pembelajaran IPA siswa diharapkan agar mendapatkan kesempatan yang besar dalam kegiatan discovery (penemuan). Siswa dituntut untuk mampu mencari tahu sendiri konsep-konsep yang ada di dalam materi IPA melalui berbagai kegiatan seperti diskusi, percobaan, serta pemecahan masalah (Kurniawati, Isnaeni, \& Dewi, 2013). Sehingga dalam mengajarkannya dibutuhkan beberapa hal diantaranya metode, media, perangkat pembelajaran dan keterampilan dalam mengajar yang disesuaikan dengan mata pelajaran IPA khususnya di sekolah dasar (Kumala, 2016). Menurut Listyawati (2012) IPA berkaitan dengan bagaimana cara mencari tahu tentang alam secara sistematis, sehingga dalam pembelajaran IPA tidak hanya pengetahuan tentang fakta, konsep, maupun prinsip, namun ada proses penemuan. Hal tersebut mempengaruhi hasil belajar yang diharapkan, yaitu sikap ilmiah dan keterampilan proses.

Hasil belajar pada pembelajaran IPA yang ingin dikembangkan terdapat tiga macam, dari pengetahuannya, sikap yang biasa dikenal sikap ilmiah dan keterampilan yang dikenal dengan keterampilan proses dalam pembelajaran IPA. Diharapkan ketiga unsur ini dapat muncul pada diri peserta didik, sehingga peserta didik dapat mengalami proses pembelajaran secara utuh memahami fenomena alam melalui kegiatan pemecahan masalah, metode ilmiah dan meniru cara dan sikap ilmuwan bekerja dalam menemukan fakta baru. Peran siswa bekerja seperti ilmuan mengandung arti bahwa dalam proses pembelajaran IPA menggunakan pendekatan keterampilan proses dasar IPA. Keterampilan proses IPA digolongkan menjadi dua bagian yaitu keterampilan dasar dan keterampilan terintegrasi. Pada siswa sekolah dasar diharapkan minimal keterampilan proses dasar IPA siswa wajib dikembangkan dalam proses pembelajaran IPA. Hal ini disebabkan kemampuan kognitif siswa sekolah dasar yang tidak dapat dibandingkan dengan struktur kognitif ilmuwan, sehingga siswa perlu diberikan kesempatan untuk berlatih keterampilan - keterampilan proses IPA yang disesuaikan dengan tahap perkembangan kognitif siswa SD (Kumala, 2016).

Piaget dalam Desmita (2011) menyatakan bahwa perkembangan siswa berada pada tahap operasional kongkrit yang membutuhkan pengalaman dan benda atau objek secara langsung. Pengalaman langsung memegang peranan penting sebagai pendorong laju perkembangan kognitif siswa pada tahapan operasional tersebut. Melalui pengalaman langsung siswa akan mengalami pembelajaran yang bermakna dan akan lebih dipahami oleh siswa, karena siswa mengalami sendiri apa yang akan dipelajari. Lebih lanjut menurut Samatowa (2011) model belajar berdasarkan pengalaman langsung memperkuat daya ingat anak dan biayanya sangat murah sebab menggunakan alat dan media belajara yang ada di lingkungan anak sendiri (Kumala, 2016).

Berdasarkan analisis dari hasil wawancara dan angket, didapatkan bahwa salah satu permainan tradisional yang dapat diterapkan sebagai metode dalam pembelajaran IPA di SDN Pleburan 03 Semarang adalah permainan tarik tambang. Permainan tarik tambang adalah permainan tradisional yang menggunakan seutas tali atau tambang. Permainan ini sudah terkenal di masyarakat. Menurut Prananta (2016) tarik tambang merupakan permainan tradisional memerlukan area dengan panjang 20 - 40 meter dan lebar 5 - 8 meter. Lalu area tersebut dibagi 2 dengan memberi garis batas antar lawan. Dari garis pembatas di tengah-tengah lalu dibuat juga garis pembatas peserta dengan panjang 2,5 meter. Teknis permainannya dengan cara masing-masing lawan menarik tali tambang sampai garis pembatas. Permainan tradisional tarik tambang mempunyai beberapa manfaat, yaitu (1) melatih kekompakan, (2) melatih percaya diri, (3) melatih kekuatan dan tanggung jawab (4) menanamkan jiwa sosial, (5) meningkatkan kebugaran, serta (6) menumbuhkan rasa cinta tanah air dan persatuan (Mulyani, 2016). Fokus penelitian ini adalah untuk mengetahui integrasi nilai karakter melalui permainan tradisional tarik tambang dalam pembelajaran IPA di Sekolah Dasar.

\section{Metode}

Penelitian ini dilaksanakan mengikuti prosedur penelitian deskripstif kualitatif dengan pendekatan Miles dan Huberman. Metode kualitatif menurut Bogdan \& Taylor (dalam Moleong, 2002) merupakan prosedur penelitian yang menghasilkan data deskriptif berupa kata-kata dari orang-orang dan perilaku yang diteliti. Subjek dalam penelitian ini adalah semua SD se-Kota semarang dengan 10 SD sebagai sampel 
penelitian. Data diperoleh melalui angket dan wawancara kemudian peneliti melakukan analisis terhadap hasil angket dan hasil wawancara. Adapun instrumen dalam penelitian ini adalah peneliti sendiri sebagaimana ciri penelitian kualitatif.

Data yang telah terkumpul lalu diuji keabsahannya melalui triangulasi sumber dan teknik. Uji keabsahan data dilakukan dengan diskusi teman sejawat dalam satu tim penelitian, triangalusi sumber yang terdiri dari hasil analisis angket dan hasil wawancara. Selain itu juga mengusahakan semua indikator pemeriksaan keabsahan data digunakan untuk memastikan bahwa data akurat dan dapat dipertanggungjawabkan. Dimulai dengan tahap identifikasi permasalahan, penentuan tema, penyusunan angket, pendistribusian angket tentang permainan tradisional yang sudah dilaksanakan guru di sekolah kepada subjek penelitian, kompilasi data, analisis data melalui deskripsi data persentase data penelitian. Adapun bagan analisis data disajikan dalam Gambar 1.

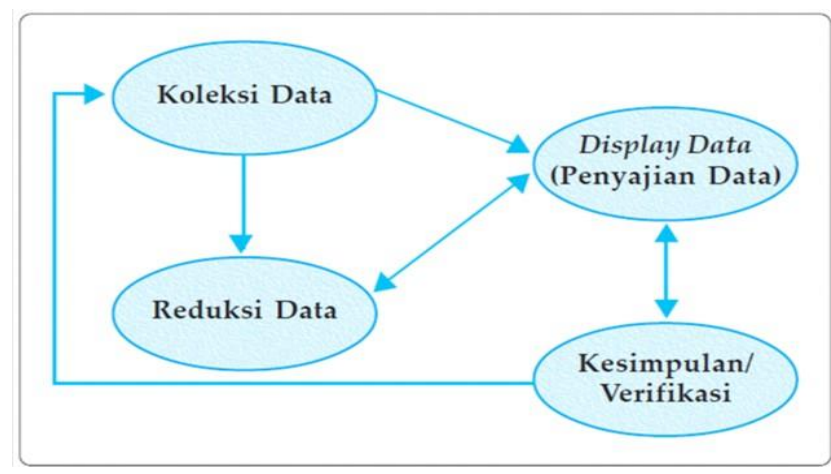

Gambar 01.

Bagan Analisis Data Kualitatif Menurut Miles Dan Huberman

\section{Hasil dan pembahasan}

Penelitian ini dilaksanakan di Kota semarang dengan subjek semua SD se-Kota semarang dengan 10 SD sebagai sampel penelitian. Hasil temuan dari analisis angket dan wawancara didapatkan bahwa Sekolah Dasar yang sudah menerapkan permainan tradisional dalam pembelajaran IPA yaitu di SDN Pleburan 03 Semarang. Hasil analisis yang diperoleh dapat dijelaskan sebagai berikut.

Cara melestarikan permainan tradisional yang sudah pernah dilaksanakan di SDN Pleburan 03 adalah dengan memperkenalkan kembali permainan tradisional pada siswa melalui pembelajaran di sekolah seperti dalam pembelajaran: (1) IPA dengan permainan tarik tambang, (2) memasukan dalam pembelajaran bahasa jawa KD tembang dolanan, (3) pada saat diadakan class meeting atau perayaan Hari Ulang Tahun Kemerdakaan Republik Indonesia dengan memainkan permainan tarik tambang, lompat tali, dan lain-lain.

Peraturan permainan tarik tambang sangat sederhana, kelompok yang mampu menarik lawan melewati garis batas maka akan menjadi pemenangnya. Jumlah pemain setiap kelompoknya pun bebas, tidak ada batasan, yang penting jumlahnya sama (imbang). Permainan tersebut dapat dimainkan oleh setiap orang mulai dari anak-anak sampai orang dewasa. Tempat yang digunakan untuk permainan tarik tambang cukup ada tanah lapang yang kosong, tidak perlu terlalu luas, bisa memakai ukuran lapangan badminton sudah cukup dan seutas tali tambang yang kuat, maka permainan tarik tambang dapat dilakukan. Permainan tarik tambang ini dapat dilakukan dalam pembelajaran IPA karena permainan tarik tambang adalah permaian tarik-menarik maka konsep yang erat hubungannya dengan materi IPA adalah Hukum Newton tentang Gerak dan Gaya. Dengan mengkombinasikan Konsep Fisika pada permainan tarik tambang, maka kita akan dapat menggunakan strategi terbaik agar dapat memenangkan permainan tersebut.

Metode permainan tarik tambang diaplikasikan dalam materi gerak dan gaya. Melalui permainan tarik tambang dan praktik secara langsung siswa dapat mengenali konsep dalam Hukum Newton. Selain dari sisi pengetahuan, hal yang lebih penting adalah terjadinya pembentukan karakter. Permainan tradisional tarik tambang mengundung nilai-nilai yang penting bagi siswa, salah satunya adalah kerja 
sama. Kerja sama adalah sikap individu yang mau melakukan suatu pekerjaan secara bersama-sama tanpa melihat latar belakang orang yang diajak bekerja sama demi mencapai tujuan yang sama. Lukita, dkk. (2012) menjelaskan bahwa sikap kerjasama dalam kelompok adalah perpaduan dari sikap masing-masing individu yang terbentuk berdasarkan komitmen bersama yang diwujudkan dalam satu sikap dan perilaku kelompok. Sejalan dengan hal tersebut, (Apriono, 2011) juga menyatakan bahwa kerjasama merupakan kemampuan yang dilakukan oleh beberapa siswa untuk saling membantu satu sama lain sehingga terbentuk suatu kebersamaan dan kekompakan yang bertujuan untuk mencapai tujuan bersama.

Sikap kerja sama yang terjalin dalam penerapan permainan tradisional tarik tambang pada pembelajaran IPA di SD Negeri Pleburan 03 memiliki beberapa kriteria mengadopsi dari hasil penelitian (Maasawet, 2011), yaitu (1) menciptakan kerjasama yang akrab, (2) mendukung keputusan kelompok, (3) menghargai keahlian anggota, (4) berpartisipasi melaksanakan tugas, serta (5) menghargai hasil kerja kelompok. Sikap kerjasama yang muncul dalam permainan tarik tambang dalam penelitian ini diantaranya siswa akan paham bahwa kegiatan tersebut adalah kegiatan kelompok atau tim. Hal ini akan menjadikan siswa mampu menekan ego masing-masing. Siswa juga akan paham bahwa dalam keberhasilan tim perlu adanya kekompakan. Masing-masing siswa dalam kelompok akan memberikan dorongan, anjuran, dan informasi pada teman sekelompoknya yang membutuhkan bantuan demi keberhasilan bersama. Kerja sama dalam permainan tarik tambang juga akan memunculkan kedisiplinan. Hal ini juga di sampaikan oleh (Wiranti, 2012) bahwa kerjasama yang baik akan menciptakan individu yang memiliki komitmen yang sama, berani, tekun, dan disiplin.

Sikap kerjasama penting dimiliki setiap siswa agar mereka mampu memahami, merasakan, dan melaksanakan aktivitas kerjasama guna mencapai tujuan bersama. Pembelajaran yang berorientasi pada kerjasama dari aspek pengetahuan dapat meningkatkan pemahaman siswa terhadap materi dengan lebih mudah. Hal ini terjadi karena siswa akan mendapat kesempatan untuk saling bertukar pendapat, gagasan, maupun pemikiran dengan siswa lainnya. Oeh karena itu, sebaiknya siswa sejak dini harus dimotivasi menanamkan sikap kerjasama atau berkelompok untuk kegiatan-kegiatan tertentu. Hal ini untuk menghindari sikap egois pada diri siswa. Sebagaimana telah dikemukakan oleh Pratiwi (2015) bahwa secara emosional masih ada siswa yang tidak mau membantu temannya serta ada beberapa siswa yang malu karena dipandang lemah jika meminta bantuan teman. Guru sebagai fasilitator dan motivator sebaiknya memberikan arahan dan kesempatan kepada siswa untuk bekerjasama membangun kekompakan dan kebersamaan dalam kegiatan pembelajaran di sekolah.

Guru di SD Negeri Pleburan beranggapan bahwa permainan tradisional sangat bisa diterapkan dalam pembelajaran di Sekolah Dasar. Mereka sudah pernah menerapkan permainan tradisional dalam pembelajaran, antara lain dalam mata pelajaran IPA pada permainan tarik tambang dalam pokok bahasan gaya dan materi tentang angin. Permainan tradisional paling sesuai diimplementasikan dalam tema keanekagaman budaya Indonesia, kegemaranku dan indahnya kebersamaan. Rata-rata guru di SD Negeri Pleburan 03 Semarang sudah pernah menerapkan permainan tradisional dalam pembelajaran di kelas. Selain mata pelajaran IPA permainan tradisional juga bisa diterapkan dalam mata pelajaran lainya tergantung dari kreatifitas dari masing-masing guru.

Para guru di SDN Pleburan 03 menyadari bahwa penerapan permainan tradisional dalam pembelajaran juga merupakan upaya dalam melestarikan permainan tradisional yang sudah banyak dilupakan. Seperti yang dikemukakan Herbert Spencer dalam Unlinear Theories of Evolution (Ritzer \& Goodman, 2009) Manusia dan kebudayaan mengalami perubahan sesuai dengan tahapan-tahapan tertentu dari bentuk yang sederhana ke bentuk yang komplek. Salah satu perubahan yang terjadi sekarang adalah mulai dilupakannya berbagai macam permainan tradisional oleh anak-anak. Anak-anak jaman sekarang lebih memilih untuk bermain permainan modern seperti game on line.

Usaha lain yang bisa dilakukan untuk melestraikan permainan tradisional antara lain: (1) mengadakan kompetisi permainan tradisional, (2) memberikan pembelajaran cara bermain permainan tradisional, (3) mengadakan pelatihan permaianan tradisional, (4) mengenalkan kembali permainan tradisional kepada anak-anak, (5) memasukan ke dalam kurikulum khususnya pendidikan jasmani. Manfaat yang bisa diperoleh dari permainan tradisional adalah memupuk kerja sama, menumbuhkan sportifitas, menumbuhkan semangat bersaing, mengasah keterampilan dan kreatifitas, mengasah kecerdasan dan kemampuan berfikir, menumbuhkan cinta tanah air, menumbuhkan solidaritas antar sesama, menumbuhkan nilai-nilai karakter misalnya kekeluragaan, kejujuran, kesederhanaan, cinta alam, saling menghargai, dan tanggung jawab. Hal ini sesuai dengan yang dinyatakan Sukirman (2008: :29) yang mengatakan bahwa permainan tradisional anak merupakan unsur-unsur kebudayaan yang tidak dapat dianggap remeh, karena permainan tradisional memberikan pengaruh yang tidak kecil terhadap perkembangan kejiwaan, sifat, dan kehidupan sosial di kemudian hari. Selain pengertian tersebut, masih ada perspektif tentang permainan tradisional yaitu perspektif fungsional, permainan, psikologis, adaptasi. Manfaat dari permainan tradisional yang sudah dirasakan oleh guru-guru di SDN Pleburan 03 antara lain: 
mengarahkan dan menuntun anak-anak pada kegiatan sosial, kebersaman yang tinggi dan didalam permainan tradisional mngajarkan anak-anak untuk bekerjasama dalam melakukan hal, melatih kesabaran, kekompakan solidaritas, saling mengharagai, sikap berjiwa besar untuk menerima kemenangan/kekalahan, melatih kemampuan fisik, melatih kerjasama, mengasah kecerdasan, meningkatankan kepercayaan diri anak, mengasah ketangkasan, melatih kepedulian terhadapa lingkungan, mengembangkan sikap sosial, dan melatih kemampuan motorik.

\section{Simpulan dan saran}

Nilai karakter yang muncul melalui permainan tradisional tarik tambang dalam pembelajaran IPA adalah kerjasama. Melalui permainan tersebut siswa mendapatkan pengalaman belajar yang bermakna berkaitan dengan materi gerak dan gaya. Kerjasama sangat penting ditanamkan sejak dini pada siswa sekolah dasar. Pembelajaran yang berorientasikan pada kerjasama selain dapat meningkatkan pemahaman siswa terhadap materi, juga dapat memberi kesempatan siswa untuk saling bertukar pendapat, gagasan, maupun ide. Sehingga saran bagi guru agar tidak malu untuk memanfaatkan permainan-permainan tradisional yang ada di daerahnya sebagai salah satu metode pembelajaran yang mampu menanamkan nilai-nilai karakter.

\section{Daftar Rujukan}

Apriono, D. (2011). Meningkatkan Keterampilan Kerjasama Siswa Dalam Belajar Melalui Pembelajaran Kolaboratif. Jurnal Prospektus, 9(2).

Desmita. (2011). Psikologi Perkembangan Peserta Didik; Panduan Bagi Orang Tua Dan Guru Dalam Memahami Psikologi Anak Usia SD, SMP,dan SMA. Bandung:Rosda Karya.

Hamid, A. (2013). Penanaman Nilai-Nilai Karakter Siswa Smk Salafiyah Prodi Tkj Kajen Margoyoso Pati Jawa Tengah. Jurnal Pendidikan Vokasi, 3(2).

Kumala, F. N. (2016). Pembelajaran IPA SD. Malang: Penerbit Ediide Infografika.

Kurniati, E. (2011). Program Bimbingan untuk Mengembangkan Keterampilan Sosial Anak Melalui Permainan Tradisional. Surakarta: Skripsi Universitas Muhammadiyah Surakarta.

Kurniawati, A., Isnaeni, W., \& Dewi, N. R. (2013). Implementasi metode penugasan analisis video pada materi perkembangan kognitif, sosial, dan moral. Jurnal Pendidikan IPA Indonesia, 2(2), 149-155. https://doi.org/10.15294/jpii.v2i2.2716

Kusmilawati, F. E., Hadi, H., \& Agustini, F. (2019). Analisis Nilai Karakter Siswa Kelas IV pada Prose Pembelajaran Bahasa Indonesia Materi Membaca. Indonesian Values and Character Education Journal, 2(1), 1. https://doi.org/10.23887/ivcej.v2i1.17923

Listyawati, M. (2012). PENGEMBANGAN PERANGKAT PEMBELAJARAN IPA TERPADU DI SMP. Journal of Innovative Science Education, 1(1), 61-69.

Lukita, \& dkk. (2012). Teori Kerjasama dan Persaingan Kelompok. Retrieved from http://www.imadiklus.com/2012/07/teori-kerjasama-dan-persaingan-kelompok.html

Maasawet, E. T. (2011). Meningkatkan Kemampuan Kerjasama Belajar Biologi Melalui Penerapan Strategi Inkuiri Terbimbing Pada Siswa Kelas Vii Smp Negeri Vi Kota Samarinda Tahun Pelajaran 2010/ 2011. BIOEDUKASI (Jurnal Pendidikan Biologi), 2(1). https://doi.org/10.24127/bioedukasi.v2i1.197

Moleong, Lexy. (2002). Metodologi Penelitian Kualitatif. Bandung: PT. remaja Rosdakarya.

Mulyani, N. (2016). Super Asyik Permainan Tradisional. Yogyakarta: Diva Press.

Nur, H. (2013). Membangun Karakter Anak Melalui Permainan Anak Tradisional. Jurnal Pendidikan Karakter, 3(1), 87-94. https://doi.org/10.21831/jpk.v0i1.1290

Prananta, I. G. N. A. C. (2016). PENGARUH PERMAINAN TARIK TAMBANG DALAM PENINGKATAN KEKUATAN OTOT TUNGKAI MAHASISWA PUTRI FPOK TAHUN 2016. Jurnal Pendidikan Kesehatan Rekreasi, 2(1), 75-79. https://doi.org/.1037//0033-2909.I26.1.78 
Pratiwi, K.M.. (2015). PENGARUH TINGKAT PENDIDIKAN, PERHATIAN ORANG TUA, DAN MINAT BELAJAR SISWA TERHADAP PRESTASI BELAJAR BAHASA INDONESIA SISWA SMK KESEHATAN DI KOTA TANGERANG. Jurnal Pujangga Volume 1, Nomor 2 (75-105).

Purwaningsih, E. (2006). Permainan Tradisional Anak: Salah Satu Khasanah Budaya yang Perlu Dilestarikan. Jantra Jurnal Sejarah Dan Budaya. Departemen Kebudayaan Dan Pariwisata Balai Kajian Sejarah Dan Nilai Tradisional Yogyakarta, 1(1).

Ritzer, G., \& Goodman, D. J. (2009). Teori Sosiologi: Dari Teori Sosiologi Klasik sampai Perkembangan Mutakhir Teori Sosial Postmodern. Yogyakarta: Kreasi Wacana.

Samatowa, Usman. 2011. Pembelajaran IPA di Sekolah Dasar. Jakarta: PT Indeks

Sisca. (2012). Aneka Permainan Outbond Untuk Kecerdasan \& Kebugaran. Yogyakarta: Bintang Cemerlang.

Tientje, \& dkk. (2004). Pendidikan Anak Usia Dini Untuk Mengembangkan Multiple Inteligensi. Jakarta: Drama Graha Group.

Tribunnews.com. 7 Oktober 2017. 24 Jam Bermain Game Online di Smartphone Mata Kanan Gadis 21 Tahun Ini Buta. http://jateng.tribunnews.com/2017/10/07/24-jam-bermain-game-online-dismartphone-mata-kanan-gadis-21-tahun-ini-buta. Diakses 20 November 2017

Wiranti. (2012). Teori Belajar dan Pembelajaran. Jakarta: Universitas Terbuka.

Yunus, A. (1981). Permainan Rakyat Daerah Istimewa Yogyakarta. Yogyakarta: Departemen Pendidikan dan Kebudayaan Proyek Inventarisasi dan Dokumentasi Kebudayaan Daerah. 